\title{
Enhanced electrodialytic bioleaching of fly ashes of municipal solid waste incineration for metal recovery
}

Helena I. Gomes ${ }^{1 \uparrow^{* *}}$, Valerio Funari ${ }^{2 \dagger}$, Enrico Dinelli ${ }^{3}$, Francesca Soavi ${ }^{4}$

\footnotetext{
${ }^{1}$ Food, Water, Waste Research Group, Faculty of Engineering, University of Nottingham, University Park, Nottingham, NG7 2RD, UK

${ }^{2}$ Dipartimento di Scienze del Sistema Terra e Tecnologie per l'Ambiente, National Research Council, ISMAR-CNR, via Piero Gobetti 101, 40129 Bologna, Italy

${ }^{3}$ Dipartimento di Scienze Biologiche Geologiche e Ambientali, BiGeA, Alma Mater Studiorum Università di Bologna, Piazza di Porta San Donato 1 - 40126, Bologna, Italy

${ }^{4}$ Dipartimento di Chimica "Giacomo Ciamician", Alma Mater Studiorum - Università di Bologna, Via Selmi 2 - 40126 Bologna, Italy
}

*Corresponding author: helena.gomes@nottingham.ac.uk

These authors contributed equally to the conception of this paper

\begin{abstract}
Metal recovery from wastes is essential for a circular economy and minimising present-day society environmental footprint. In this study, we combined electrodialysis with bioleaching of fly ashes for enhanced metal recovery from municipal solid waste incineration residues. Results showed that the use of low-level direct current with acidophilic bacteria enhanced metal recovery in the catholyte when compared to the abiotic experiment supplied with direct current and the bioleaching experiment without direct current. The use of electrodialysis with bioleaching showed increased performance on the removal and recovery of metals in the
\end{abstract}


catholyte such as $\mathrm{Al}, \mathrm{Cd}, \mathrm{Co}, \mathrm{Li}, \mathrm{Pb}$, and $\mathrm{Zn}$. While $\mathrm{Co}$ and $\mathrm{Ni}$ were selectively mobilised by bioleaching, $\mathrm{Cu}, \mathrm{Cr}, \mathrm{Cd}$ and Li showed highly elevated concentrations by combining both techniques. These results are proof of concept of combined methods will allow optimising the process, especially varying the liquid to solid ratio, mixing, duration of the experiments, and $\mathrm{pH}$ control in the anolyte.

Keywords: Resource recovery; Circular Economy; Waste Management; Biotechnology; Combined technologies

\section{Highlights}

- Proof of concept that bioleaching and electrodialysis can be combined

- Electrodialysis enhanced bioleaching metal recovery from MSWI fly ashes

- Substantial amounts of metals were retained in the ion exchange membrane

\section{Introduction}

Incineration is one of the prevailing solutions adopted globally for the management of municipal solid waste [1]. Municipal solid waste incineration (MSWI) has the advantage of recovering energy and reducing waste volume. Nonetheless, it destroys technical value in wastes that is no longer available to the circular economy [2], for example, considering the butterfly diagram, paper can no longer be re-pulped to produce recycled paper remaining in the technosphere, and it can no longer be composted, returning organic matter to the biosphere [3]. Fly ash (FA) and bottom ash (BA) of MSWI are low concentration streams of metals classed as critical raw materials (both of high economic importance for the European Union and vulnerable to supply disruption)[4] and essential to the development of new and green technologies, with estimated annual flows of tens of kilograms and a total metal 
content comparable to low-grade active mines [5]. Circular economy and resource recovery must ensure the return of materials and elements from anthropogenic use to natural reserves [6]. There is a pressing need for these critical and scarce metals remaining in FA and BA to be extracted and recovered using sustainable technologies [7].

Bioleaching is a reliable hydrometallurgical technology that reached a technology readiness levels (TRL) as high as to be commercially used for the processing of low-grade ores (e.g. copper sulphide ores) [8,9]. It uses the metabolic reactions of certain microorganisms to solubilise metals, mainly through the production of acidic substances [10]. Acidophile bacteria reduce sulphur species $\left(\mathrm{S}_{8}, \mathrm{~S}_{2} \mathrm{O}_{3}{ }^{2-}, \mathrm{H}_{2} \mathrm{~S}\right.$, or polysulphides) to sulphuric acid, and oxidise ferrous $\left(\mathrm{Fe}^{2+}\right)$ to ferric iron $\left(\mathrm{Fe}^{3+}\right)$ [11]. Both $\mathrm{Fe}^{3+}$ and $\mathrm{H}^{+}\left(\right.$from $\left.\mathrm{H}_{2} \mathrm{SO}_{4}\right)$ solubilise the metals from secondary wastes through contact and non-contact mechanisms (e.g. thiosulphate pathway, polysulphide pathway) [11]. At bench scale, it has been used successfully for both municipal solid waste incineration bottom ashes (BA) and fly ashes (FA) [12], but also other alkaline wastes such as steel slag [10]. In MSWI residue testing at the bench scale, metal bioleaching can be higher than $90 \%$ for $\mathrm{Mg}$ and $\mathrm{Zn},>85 \%$ for $\mathrm{Al}$ and $\mathrm{Mn}$, and between 65 to $50 \%$ for $\mathrm{Cr}, \mathrm{Ga}, \mathrm{Ce}, \mathrm{Nd}, \mathrm{Pb}$, and $\mathrm{Co}$ [12]. Other studies show $90 \%$ removal of $\mathrm{Zn}, \mathrm{Cu}$, and only $10 \%$ removal of from FA [13].

Electrodialytic removal of metals was tested on different types of FA from MSWI $[14,15]$ at bench scale, but further research is needed to reach higher TRL. The main transport mechanisms involved in electrodialytic and electrokinetic remediation are electromigration, electrophoresis, and electroosmosis [16]. Water electrolysis at the electrodes generates $\mathrm{H}^{+}$in the anode, and subsequently, a flowing acid front (controlled by cells geometry) that is responsible for metal solubilisation and electromigration of the metal cations. Metal removals from FA by electrodialytic remediation were below 5\% for most metals, while up to $61 \% \mathrm{Cd}$ and $53 \% \mathrm{Zn}$ were removed [14]. 
Bioleaching and electrodialysis combined (or in sequence) were recently used on tungsten mine wastes [17], zinc remediation of soil contaminated by tannery effluent [18], and phosphorus recovery from the bioleachate of sewage sludge ash [19], but never to recover metals from MSWI fly ashes. The application of direct current could avoid or minimise the need to add acids during bioleaching, due to the generation of $\mathrm{H}^{+}$in the anode. However, previous studies with tungsten mine wastes and pure bacterial cultures in a single chamber electrochemical cell showed that direct current (up to $1.5 \mathrm{~V}$ ) inhibited bacterial growth in Acidithiobacillus spp., resulting in a detrimental effect on metal extraction efficiency [17]. Further research is needed to assess how both techniques can be integrated.

Chronoamperometry is an electrochemical technique that enables to measure of the current flowing over time in a cell at a given cell voltage. In the case of electrolytic cells, like MRC, the voltage is applied by an external source. The current is related to the charge, i.e. the number of electrons, exchanged between the electrodes through the external circuit over time. According to the Faraday law of the electrolysis, the amount of material transformed by the an electrochemical reaction is directly proportional to the charge transferred between the electrodes. The relation between charge and moles of reactants depends on the cell reaction stoichiometry. Therefore, the current is an indication of the cell electrochemical reaction rate. Integration of the current over time provides the total charge and, consequently, the total amount of material that has reacted by the electrochemical path. In an MRC, different chemical, biochemical, and bioelectrochemical reactions take place. Therefore, chronoamperometry allows to evaluate the contribution of the bioelectrochemical process over the whole MRC processes. Specifically, it can be used to measure the yield of electrochemical metal recovery.

Chronoamperometry, a fundamental technique in electrochemistry, was successfully applied on conducting polymers, ion-selective electrodes, and reverse osmosis [20], and is used to demonstrate the utility of the chronoamperometric response during the application 
and pause times of the external electric potential in determining transport parameters of electrodialytic systems. On the other hand, when the cell voltage is imposed to a zero value, the chronoamperometric response allows measures of the short circuit current, which informs in conventional electrodialysis, as well as in reverse electrodialysis for electric energy generation. Chronoamperometry results can thus provide a ground basis on electrochemically assisted recovery of metals from incineration FA.

This work aims to investigate if bioleaching can be coupled with electrodialytic remediation (ED) to enhance metal recovery from FA of MSWI, and simultaneously to demonstrate proof of concept of a microbial recovery cell (MRC). Bioleaching is deployed with a mixed acidophilic bacterial culture as reported elsewhere $[9,16]$, and we hypothesise that it can be used jointly with ED to recover metals from low-grade residues of municipal solid waste incineration. Furthermore, we conducted a detailed study of the chronoamperometric response of MRC systems under selected bioleaching conditions.

\section{Materials and Methods}

\subsection{Chemicals}

Sulphuric and nitric acid (95-97\%) were trace metal grade (CARLO ERBA Reagents). Following the previous experiences on bioleaching of MSWI residues [12, 13], the modified 9K medium was prepared with following chemicals (analytical grade, MERCK) according to Silverman and Lundgren, 1957: $\left(\mathrm{NH}_{4}\right)_{2} \mathrm{SO}_{4} 3.0 \mathrm{~g} \mathrm{~L}^{-1}, \mathrm{~K}_{2} \mathrm{HPO}_{4} 0.5 \mathrm{~g} \mathrm{~L}^{-1}$, $\mathrm{MgSO}_{4} \cdot 7 \mathrm{H}_{2} \mathrm{O} 0.5 \mathrm{~g} \mathrm{~L}^{-1}, \mathrm{KCl} 0.1 \mathrm{~g} \mathrm{~L}^{-1}, \mathrm{Ca}\left(\mathrm{NO}_{3}\right)_{2} 0.01 \mathrm{~g} \mathrm{~L}^{-1}, \mathrm{FeSO}_{4} \cdot 7 \mathrm{H}_{2} \mathrm{O} 22.5 \mathrm{~g} \mathrm{~L}^{-1}$, and 10.0 $\mathrm{g} \mathrm{L}^{-1} \mathrm{~S}^{0}$. The water was deionised with a Milli-Q purifier system (Millipore Corp., Bedford, MA, USA). The catholyte used in the experiments was a $0.01 \mathrm{M} \mathrm{NaCl}$ (MERCK pro analysis) solution.

\subsection{Fly ash characterisation}


The studied fly ash (FA) comes from an Italian Waste-to-Energy plant equipped with a grate-furnace system, which burns $90 \%$ household waste and $10 \%$ special waste (including metallurgical slag, automotive shredder residue, and medical wastes). According to the company report, the municipal waste processing capacity of the selected incinerator is $1.4 \times 10^{5}$ tonnes per year, while the total FA produced is around $3 \times 10^{3} \mathrm{t} / \mathrm{a}$. A representative amount of $20 \mathrm{~kg}$ of primary sample was taken from a big bag of the dry scrubber after blending a large number of increments, as in Funari et al. [5]. The dry scrubber is located after the combustion chamber within the air pollution control system (APC) and followed by further chemical filters as to allow a multi-step cleaning of the flue gas and the separate recovery of other solid residues not considered in this study. The collected sample, hereafter called SFA, represents the least cleaned material, so high metal loaded, recovered into the big bag during regular operation of the combustor. The SFA is a fine-grained and dusty material with colour and grain-size rather homogeneous upon visual inspection; nonetheless, further material pre-treatment included drying at $50{ }^{\circ} \mathrm{C}$ for $48 \mathrm{~h}$ and thorough milling in an agate vibratory disk mill. The bulk chemical composition of the starting material after total digestion is given in Table 1. The $\mathrm{pH}$ of the starting material in normal conditions equals to 12.

\subsection{Microbial culture}

In the bioleaching experiments, we employed a mixed culture of acidophilic bacteria isolated from a natural area [13], primarily containing sulphur and iron oxidising bacteria. Such microorganisms community was already tested in bioleaching of MSWI residues, and the overall efficacy resulted comparatively similar of (abiotic) sulfuric acid leaching [12] and better than bioleaching using alkaline strains [21]. The used culture resulted from adaptation to MSWI residues $[10,12,13]$ and conditioning in $250 \mathrm{~mL}$ Erlenmeyer flasks containing 
90\% (v/v) modified $9 \mathrm{~K}$ medium on a shaker incubator (Infors HT Multitron Standard). Thereby, culture is incubated at $150 \mathrm{rpm}$ and $30{ }^{\circ} \mathrm{C}$ and renewed to enhance the cell activity by regularly inoculating $10 \%(\mathrm{v} / \mathrm{v})$ of former cultivations and $90 \%(\mathrm{v} / \mathrm{v})$ of the modified $9 \mathrm{~K}$ medium. The $\mathrm{pH}$ was maintained below 2.5 using concentrated $\mathrm{H}_{2} \mathrm{SO}_{4}$, as required, since acidophilic bacteria like At. ferrooxidans and At. thiooxidans thrive at this $\mathrm{pH}$ [22]. Sulphur and iron cycling are important parameters during bioleaching, closely associated with the planktonic microbial community structure and its physiological and biochemical diversity [23]. To sustain an active microbial population of iron oxidisers, $1.0 \mathrm{~g} / \mathrm{L} \mathrm{Fe}^{3+}$ is supplied as $\mathrm{FeSO}_{4} \cdot 7 \mathrm{H}_{2} \mathrm{O}$, while elemental sulphur $(10.0 \mathrm{~g} / \mathrm{L})$ fed sulphur-oxidising bacteria to achieve sulphuric acid production and further promote leaching via ferrous iron oxidation [24]:

$4 \mathrm{Fe}^{2+}+4 \mathrm{H}^{+}+\mathrm{O}^{2} \rightarrow 4 \mathrm{Fe}^{3+}+2 \mathrm{H}_{2} \mathrm{O}$ (iron-oxidizing bacteria participate) [eq. 1] $2 \mathrm{~S}^{0}+3 \mathrm{O}_{2}+2 \mathrm{H}_{2} \mathrm{O} \rightarrow 2 \mathrm{SO}_{4}^{2-}+4 \mathrm{H}^{+}$(sulphur-oxidizing bacteria participate) [eq. 2]

\subsection{Experimental setup}

We performed three experiments in a two-compartment electrodialytic cell with a total volume of $120 \mathrm{~mL}$ using a cation exchange membrane (CMI-7000 S; Membranes International, Inc.) as a separator. Each compartment measures $5 \mathrm{~cm} \times 5 \mathrm{~cm} \times 5 \mathrm{~cm}$ with an internal volume of $60 \mathrm{~mL}$ (Figure 1). The experiments were conducted at room temperature for $96 \mathrm{~h}$, with constant stirring in an orbital shaker at $150 \mathrm{rpm}$, to test the effect of low-level direct current in abiotic and biotic conditions, being the latter supplied in the anode compartment with $10 \% \mathrm{v} / \mathrm{v}$ of bacterial inoculum (Table 2 ). The metal removal performance of bioleaching in presence/absence of direct current was also tested in control experiments. In the electrodialytic (ED) setups, a low constant voltage $\left(1.0 \mathrm{~V} ; 0.20 \mathrm{~V} \mathrm{~cm}^{-1}\right)$ was supplied by a DC power supply (KERT KAT 10VD). The FA sample was placed in the anode compartment 
in a liquid/solid ratio of 10:1, with modified $9 \mathrm{~K}$ medium ( $5 \mathrm{~g}$ of fly ash, $5 \mathrm{~mL}$ of inoculum, $45 \mathrm{~mL}$ of modified $9 \mathrm{~K}$ medium, and $0.5 \mathrm{~mL}$ concentrated $\mathrm{H}_{2} \mathrm{SO}_{4}$ ) [12]. The catholyte used was $0.01 \mathrm{M} \mathrm{NaCl}$, and the electrodes were graphite rods (Alfa Aesar), with $10 \mathrm{~cm}$ length and $6 \mathrm{~mm}$ diameter. Samples for analysis were collected at 2, 4, 6, 24, 48, 72, and $96 \mathrm{~h}$. Samples were collected from both the anode and the cathode compartment. Samples from the anode compartment are a slurry, as they contain suspended particles of the fly ash, while samples from the catholyte are aqueous solutions. Both samples were filtered through a $0.45 \mu \mathrm{m}$ filter, and acidified with high purity $\mathrm{HNO}_{3}$ before ICP analysis. In the same time points, the $\mathrm{pH}$ in the anolyte and the catholyte was measured at each sampling using a $\mathrm{pH}$ meter Eutech Instruments.

\subsection{Chronoamperometry testing for optimisation in microbial fuel cells}

In the experimental cell monitored through chronoamperometry testing, the same cation-exchange membrane (CMI-7000 S; Membranes International, Inc.) was placed between two compartments, which were also identical to the previous experiments. As such, we studied both biotic and abiotic leaching, where the latter can be considered as control experiment. Solution in cell is under natural convection conditions, since under chronoamperometry testing stirring with an orbital shaker was unfeasible. Both compartments were pre-acidified to a setpoint $\mathrm{pH}$ of 3 with conc. $\mathrm{H}_{2} \mathrm{SO}_{4}$ and $\mathrm{HCl}$ for anolyte and catholyte, respectively. The acid pre-treatment of MSWI fly ash is necessary because these residues have high starting $\mathrm{pH}$ (ca. 13) and buffering capacity that would hinder both acidophilic bacteria growth and removal of metals. In normal conditions, moreover, heavy metals should exist in oxidizable and reducible states. Contrarily to the experiments without chronoamperometry monitoring, the use of mineral acid in the monitored experiments can offset these limiting factors including the lack of appropriate stirring which, in turn, impedes 
good aeration in the bioleaching system. The measurements were carried out at $25{ }^{\circ} \mathrm{C}$ using a Biologic VSP multichannel potentiostat/galvanostat. In this case, the electric current density through the system is measured at a selected cell voltage.

Chronoamperometry allowed the measurement of the current under an applied cell voltage. By this approach, the oxidative processes are forced at the anolyte compartment (positive terminal) and reduction takes places at catholyte (negative terminal). From the integral of the current, it is possible to calculate the charge (i.e., number of electrons) that have passed throughout the circuit.

Two channels of the potentiostat/galvanostat were used. One channel was used to drive the electrochemical reactions by a 2-electrode setup. Specifically, a difference of potentials was applied between the graphite rod in contact with the anolyte (that acted as the working electrode) and the rod immersed in the catholyte. The latter was connected to the counter electrode, a reference electrode plugs of the instrument. In parallel, a second channel of the instrument was used to monitor the potential of each electrode over time vs an $\mathrm{Ag}$ / $\mathrm{AgCl}$ reference electrode by a 3-electrode setup. For this measure, the anolyte rod was connected to the working electrode plug, the catholyte rod was connected to the counter electrode plug, the $\mathrm{Ag} / \mathrm{AgCl}$ electrode was connected to the reference.

\subsection{Analysis}

A Perkin Elmer ELAN DRC-e Inductively coupled plasma mass spectrometer (ICPMS) was used for the determination of the total elemental composition of SFA solid sample and process solutions. The solid SFA was analysed using as a method of total digestion for MSWI residues, as in [5], the sodium peroxide sintering technique described elsewhere [25]. Blank solutions and reference materials were also treated similarly before final measurements with ICP-MS to assess accuracy and instrument drift. The precision, based on replicated 
analyses of samples and standards, is estimated as better than $10 \%$ for all elements well above the detection limit. Small aliquots of process solutions, resulted from filtration at 0.45 $\mu \mathrm{m}$ paper filter under vacuum aspiration and pre-acidification with concentrated $\mathrm{HNO}_{3}$, were dissolved entirely with aqua regia in closed Falcon $50 \mathrm{~mL}$ conical centrifuge tubes until the solution was clear. Many blanks and reference samples with known elemental composition were quantified for quality control. For the process solution, precision is estimated better than $10 \%$ for all elements, but $\mathrm{Al}, \mathrm{Fe}$, and $\mathrm{Pb}$. Determination of $\mathrm{Ca}$ and $\mathrm{K}$ experienced a significantly lower accuracy compared to other analytes. Element quantification for Al, Ca, Fe, Mg, K, Na, Mn, Zn, Cu, Pb, As, Ba, Cd, Cr, Co, Li, Mo, Ni, Sr, Ti, and V employed calibration curves prepared with diluted standard solutions from ICP multielement standard solution XXI (Merckgroup). Also, we probed the elemental impurity of the reagents employed throughout the experiments via ICP-MS measurements for accurate assessment of the leaching yields.

\subsection{Statistical analysis}

Statistical analysis to compare the experimental conditions tested was carried out in RStudio [26] perform ANOVA and Tukey test. A two-way repeated measures ANOVA considering the totality of data and detailing for experimental conditions (electrodialytic process, bioleaching, bioleaching and electrodialysis) and cell compartments (anolyte, anode, membrane, cathode, catholyte) was performed. 


\section{Results and Discussion}

\section{$3.1 \mathrm{pH}$ variation}

The $\mathrm{pH}$ values (Fig. 2) measured show that the production of $\mathrm{H}^{+}$in the anode due to the oxidation of water (eq. 3) is buffered by the calcium oxides and calcium aluminium silicates present in the fly ash, whose dissolution increases alkalinity (eq. 4-6) [27]. The values measured are similar in the anolyte and the catholyte in all the experimental conditions $(\mathrm{pH} \sim 5)$. Only the catholyte in the control electrodialytic experiment (ED) showed values up to 8 in the first ten hours, and then decrease until stabilising at $\mathrm{pH} 5$.

$$
\begin{aligned}
& 2 \mathrm{H}_{2} \mathrm{O}(\mathrm{l}) \longrightarrow \mathrm{O}_{2}(\mathrm{~g})+4 \mathrm{H}^{+}(\mathrm{aq})+4 \mathrm{e}^{-} \\
& \mathrm{CaO}(\mathrm{s})+\mathrm{H}_{2} \mathrm{O}(\mathrm{l}) \leftrightarrows \mathrm{Ca}(\mathrm{OH})_{2}(\mathrm{aq}) \\
& \mathrm{Ca}(\mathrm{OH})_{2} \leftrightarrows \mathrm{Ca}^{2+}(\mathrm{aq})+2 \mathrm{OH}^{-}(\mathrm{aq})
\end{aligned}
$$

The $\mathrm{pH}$ values show that the low voltage applied in the experiments does not generate enough $\mathrm{H}^{+}$to provide optimal conditions to the acidophilic bacteria. Both iron and sulphuroxidising bacteria can grow at $\mathrm{pH}$ 1.0-2.0, with a low $\mathrm{pH}$ required for the iron cycle [28]. Lower $\mathrm{pH}$ values would also increase the dissolution of metals [29]. Further optimisation of the combination of the two techniques either will demand acid addition to ensure optimal $\mathrm{pH}$ values or higher applied voltages. However, the latest can be damaging for the bacteria as the application of electric current disrupts bacterial membrane by changing the orientation of membrane lipids [30]. There is the likelihood that bioleaching bacteria were not able to thrive under these $\mathrm{pH}$ conditions, so although the measured concentrations in both catholyte and anolyte allow to follow the variation in metal mobility and ionic flows throughout the cell compartments, useful information on actual electromigration might derive from the monitored experiments where the $\mathrm{pH}$ setpoint was manually adjusted. Noteworthy, the ED 
experiment in the catholyte (Fig. 2b) showed a sharp increase of $\mathrm{pH}$ in the first seven hours, likely due to buffering from migration of readily soluble metals such as those forming alkali salts. After 8 hours the $\mathrm{pH}$ curve started to slowly even out due to the production of $\mathrm{H}^{+}$as a consequence of the flowing currents applied. Furthermore, the $\mathrm{pH}$ level of the microbial leaching cell without energy supply (Exp. 2, Fig. 2b) decreased after fifty hours onwards. This phenomenon might relate to bioproduction of sulphuric acid by S-oxidizers bacteria that spontaneously, i.e., without external supply of energy, forced reduction at the catholyte under the selected experimental configuration.

In the experiments powered by the microbial fuel cell in chronoamperometry testing mode, similar $\mathrm{pH}$ values were recorded in the anode (average $\mathrm{pH} 2.6$ ) and the cathode (average $\mathrm{pH}$ 2.7) at the end of the experiments due to acid addition in both anode and cathode compartments, showing $\mathrm{pH}$ conditions favourable to the thriving of acidophilic bacteria, and consequently metal recovery by bioleaching. From the setpoint $\mathrm{pH}$ of 3 , the $\mathrm{pH}$ slightly decreased in both anodic and cathodic compartments likely due to the activity of acidophilic bacteria and stabilized at the end of the experiment providing clues of electrochemical reversibility.

\subsection{Metal concentrations in the anolyte}

Most metal concentrations in the anode compartment show the general trend of decreasing exponentially over time when combining bioleaching with electrodialysis [Exp. 3, Fig. 3 a) and b)]. Metals such as $\mathrm{Co}, \mathrm{Zn}, \mathrm{Li}, \mathrm{Pb}$, and $\mathrm{Ni}$, present a slightly different behaviour with slower decreases over time [Fig. $3 \mathrm{c})$ and d)]. Cadmium (Cd) is the exception and tends to increase over time, accumulating in the anolyte when using electrodialysis and bioleaching simultaneously. The highest metal concentrations were always found when combining electrodialysis and bioleaching (Exp. 3), showing that more metals were solubilised and 
mobilised using both techniques. Table 3 shows the concentrations measured in the anolyte two hours after the start of the experiments and at the end, as well as the percentage variation observed. In the majority of cases, there is a decrease in the metal concentration, except for Co in the bioleaching experiment, $\mathrm{Sr}$ in the electrodialytic and bioleaching controls, and $\mathrm{Cd}$ when combining ED and bioleaching. In the MFC powered experiment, all the metals increased their concentration due to the initial acid addition. Here the element mobility increases or remains constant with time, contrarily to the previous experiments where they show an overall decrease after 96 hours. Even if similar experiments on bioelectrochemical systems had a longer timeframe [9, 24], long-term behaviour and eventual enhancement of leaching concentrations with time cannot be assessed, as we set an experiment duration of four days to evaluate the immediate effect of energy supply.

\subsection{Metal concentrations in the catholyte}

Metal concentrations in the cathode compartment are higher when combining the electrodialytic treatment (ED) with bioleaching (Exp. 3), and for $\mathrm{Cu}, \mathrm{Zn}, \mathrm{Li}, \mathrm{Co}, \mathrm{Pb}$, and $\mathrm{Ni}$, there is a sharp increase in the concentration in the last $24 \mathrm{~h}$ (Fig. 4). The highest concentrations measured in the catholyte correspond to $\mathrm{Zn}\left(28.4 \mathrm{mg} \mathrm{L}^{-1}\right), \mathrm{Cd}\left(22.6 \mathrm{mg} \mathrm{L}^{-1}\right)$, $\mathrm{Al}\left(21 \mathrm{mg} \mathrm{L}^{-1}\right), \mathrm{Pb}$, and $\mathrm{Sr}\left(10.2 \mathrm{mg} \mathrm{L}^{-1}\right)$ when combining electrodialysis with bioleaching (Exp. 3). The metal concentrations are statistically significant higher when combining both techniques. The metals solubilised by bioleaching are transported to the cathode compartment by electromigration in a synergistic effect, which explains the higher concentrations, when compared with the control experiments (Exp. 1 and 2). This synergistic effect can be explained by increased solubilisation of metals and high transport rates due to electromigration promoted by the low level direct current [18]. Other studies reported an 
increase in activity and growth rate of iron oxidizing bacteria, which rapidly oxidized more $\mathrm{Fe}^{2+}$ to $\mathrm{Fe}^{3+}$, resulting in a faster $\mathrm{Cu}$ leaching from e-wastes [31].

Previous studies with electrodialytic treatment of ashes and air pollution control residues had longer durations (14 days) [14, 32], and further extended testing would allow to assess the increase in metal recovery in the cathode compartment. Another critical factor to consider for optimising the combination of both techniques is $\mathrm{pH}$ control, so the speciation of metals [19] for further recovery can be maximised, to avoid uncontrolled precipitation.

\subsection{Statistical analysis}

A two way repeated measures ANOVA considered the experimental setup and cell compartment concentrations as factors for the totality of data. The ANOVA determined that there was a statistically significant difference $(p<0.05)$ between experimental conditions for all the parameters considered (Table 3 ). Also, there was a statistically significant difference between the concentrations found in each cell compartment for all the parameters considered, except for Sr. The interaction effect - whether there is more impact on metal concentration from experimental setup and cell compartment than could be explained by the two influences alone - was also significant for all parameters, but the values of $\eta^{2}$ are in most cases below 0.2 , meaning that the interaction effect between the two factors explains little of the determinants variance. For aluminium, the interaction effect is the most relevant factor, explaining $44 \%$ of the variance. In general, the experimental setup is the most critical factor, with large $\eta^{2}(>0.14$ according to Cohen's guidelines). This means that most of the variance is due to the different experimental setups.

Tukey tests show that the combination of bioleaching and electrodialysis is statistically significant from both bioleaching and electrodialysis separately for all the metals considered. The metal concentrations found in the membranes were also significantly 
different from the ones in the cathode and the anode compartment for the majority of metals. Only $\mathrm{Cr}$ and $\mathrm{Sr}$ amounts were just statistically different between the membrane and the cathode compartment.

\subsection{Chronoamperometry}

Two different cell voltages of $0.5 \mathrm{~V}$ and $1.0 \mathrm{~V}$ were applied between anolyte and catholyte, the oxidative processes are forced at the anolyte and reduction takes places at catholyte. In these experiments, the $\mathrm{pH}$ values slightly decreased from the setpoint $(3 \mathrm{pH})$, in both anode $(2.6 \mathrm{pH}$ in $1.0 \mathrm{~V}$ experiment $)$ and cathode $(2.7 \mathrm{pH}$ in $1.0 \mathrm{~V}$ experiment $)$ compartments likely due to bacteria activity, and is nearly stabilized at the end of the experiment providing clues of electrochemical reversibility. This is consistent with other studies which concluded that dissolved ions are continuously being removed during electrodialytic treatments, so no equilibrium is obtained between ash and solution [29]. Under the application of $0.5 \mathrm{~V}$ over 86400 seconds only 3.566 Coulombs were measured. By applying a cell voltage equal to $1.0 \mathrm{~V}$ over 345600 seconds, the charge is 110.529 Coulomb (Fig. 5). According to the Faraday law, this charge corresponds to $1.145 \times 10^{-3} \mathrm{~mol}$ of electrons. Assuming that, at the average, 2 electrons are implied for the transformation of 1 mol of inorganic compounds, this value results in the electrochemical conversion of $0.72 \times$ $10^{-3}$ mol of these compounds. In turn, this latter value can be taken as the total amount of metal cations that are released in solution. With further assumption, we do not take into account electrolysis of electrolytic components in the system since, like oxidation of oxygen from water, can be ruled out at electrode potentials more positive than $0.0 \pm 0.2 \mathrm{~V}$ vs ref.1 in the anolyte (Fig. 5), and we hypothesized that the major cations in Table 5 (in decreasing order of concentration in solution: $\mathrm{Al}, \mathrm{Ca}, \mathrm{Zn}, \mathrm{Ti}, \mathrm{Mn}, \mathrm{Cu}, \mathrm{Cr}, \mathrm{Sr}$, and $\mathrm{Pb}$ ) are flowing in the 
circuit and primarily load the process solution. Using their relative atomic masses and the measured concentrations by ICP-MS at the end of the experiment, around 0.06 moles can be calculated as the total moles of metal species that passed through the system (to the catholyte or retained onto the membrane) under the selected conditions. Therefore, the moles of electrochemically converted species represent around less than $1.3 \%$ of inorganic compounds virtually mobilised. This small electrochemical contribution is likely consistent to the slight solubility enhancement that can be seen from Fig. 3 and Fig. 4 for the "ED and bioleaching" trends. Although the electrochemical contribution is nearly negligible for the purpose of metal recovery under the imposed experimental configurations, the combined process of ED plus bioleaching for the treatment of FA demonstrated good promises for optimization because the active surface of graphite electrodes can be increased easily using bigger rods or electrodic nets commercially available.

From another point of view, around 300 grams per litre of leachate is the weight of electrochemically converted inorganic compounds. This figure, in turn, stands for the total mass of metals that are potentially recoverable from one litre of process solution (leachate) under the experimental conditions.

\subsection{Metals distribution}

A relevant fraction of the metals is accumulating in the cation exchange membrane (Fig. 6). Membranes are used in electrodialytic remediation to minimise energy for the transport of highly mobile ions (e.g. $\mathrm{H}^{+}$or $\left.\mathrm{OH}^{-}\right)$instead of the target species, but also to prevent the return of the mobilized contaminants to the compartment where the solid matrix

is [33]. In the electrodialytic control experiment, between $6-65 \%$ of the metals are concentrated in the cation exchange membrane. Other matrices such as $\mathrm{LiCoO}_{2}$ powder from used bateries also had limited recovery due to accumulation in the cation exchange 
membrane [34]. This means that other types of membranes or reactors maybe be more adequate for metal recovery using the combined technologies. Only $6 \%$ of $\mathrm{Li}$ was in the membrane, followed by $9 \%$ of $\mathrm{Cd}$, Co and $\mathrm{Zn}, 13 \%$ of $\mathrm{Sr}, 15 \%$ of $\mathrm{Cu}, 17 \%$ of $\mathrm{Ni}, 18 \%$ of $\mathrm{Al}$, $46 \%$ of $\mathrm{Pb}$, and $65 \%$ of $\mathrm{Cr}$. This is directly related with the metals atomic radius, as both $\mathrm{Pb}$ and $\mathrm{Cr}$ have the highest atomic radius and are retained more easily in the pores of the membrane. The bioleaching control experiment showed lower metal amounts in the membrane (4-24\%), as the absence of the low-level direct current did not compel electromigration of metals to the cathode. While combining both technologies, the percentages of metals retained in the membrane are similar, varying between $31 \%$ and $40 \%$.

More metals are also deposited in the cathode when using both electrodialysis and bioleaching (31-55\%), compared to electrodialysis (average of 13\%), and bioleaching (average of 6\%). The bioleaching experiment acts as a control showing that cations that cross the membrane can also adhere to the graphite electrode. Graphite is known to be a good support material for metals because of its inertness, mainly through metal-carbon adsorption bonds [35]. The combination of both technologies appears to favour electrodeposition in the cathode when comparing them individually. It is also evident that lower amounts of metals $(0.4-40 \%)$ can be found in the anolyte when using electrodialysis (13-87\%) and bioleaching (5-67\%). This is consistent with other studies, which concluded that dissolved ions are continuously being removed during the electrodialytic treatments so no equilibrium is obtained between ash and solution, with the continuous removal enhancing dissolution processes [36]. 


\section{Conclusions}

Fly ashes from municipal solid waste incineration are complex matrices and can be sources of critical raw materials in the circular economy, and we need novel technologies that allow resource recovery. This study constitutes the first proof of concept that bioleaching can be enhanced when combined with electrodialytic remediation for metal recovery from fly ashes. When associating both methods, higher mobilisation of metals was observed, with higher metal concentrations in both anode and cathode compartments, in particular for $\mathrm{Cu}$ and $\mathrm{Cr}$. We also observed substantial metal accumulation in the cation exchange membrane, which highlights the need for further developments on membranes or other types of reactors that can allow better separation of the elements. Further optimisation is still needed in particular regarding $\mathrm{pH}$ in the anode to ensure better conditions for bacteria survival, bacteria adaptation to alkaline wastes, liquid to solid ratio, mixing, and duration of the experiments. Further testing with other ashes (or alkaline wastes) and consortia would consolidate these results.

\section{Acknowledgements}

H.I. Gomes acknowledges the University of Nottingham for her funding through an Anne McLaren Fellowship. The funding of a Short Term Scientific Mission (STSM) by the COST Action CA15115 supported this work (ECOST-STSM-Request-CA15115-43318). F. Soavi acknowledges the Italy-South Africa joint Research Programme 2018-2020 supported by the Italian Ministers of Foreign Affairs and of the Environment. V. Funari and E. Dinelli acknowledge the analytical data for process solutions presented in this paper as the first contribution of Laboratorio di Geochimica "Bruno Capaccioni" dedicated to the memory of 
Bruno, enthusiastic professor and geochemist, who regrettably passed away before the installation of the ICP-MS facility at BiGeA. 


\section{References}

[1] A. Joseph, R. Snellings, P. Van den Heede, S. Matthys, N. De Belie, The use of municipal solid waste incineration ash in various building materials: A Belgian point of view, Materials, $11(2018) 141$.

[2] P. Purnell, On a voyage of recovery: a review of the UK's resource recovery from waste infrastructure, Sustainable and Resilient Infrastructure, 4 (2019) 1-20.

[3] E. Iacovidou, C.A. Velis, P. Purnell, O. Zwirner, A. Brown, J. Hahladakis, J. MillwardHopkins, P.T. Williams, Metrics for optimising the multi-dimensional value of resources recovered from waste in a circular economy: A critical review, Journal of Cleaner Production, 166 (2017) 910-938.

[4] G. Blengini, D. Blagoeva, J. Dewulf, C. Torres de Matos, V. Nita, B. Vidal-Legaz, C. Latunussa, Y. Kayam, L. Talens Peirò, C. Baranzelli, Assessment of the methodology for establishing the EU list of critical raw materials: Background report, JRC Technical Reports, (2017).

[5] V. Funari, R. Braga, S.N.H. Bokhari, E. Dinelli, T. Meisel, Solid residues from Italian municipal solid waste incinerators: A source for "critical" raw materials, Waste Management, 45 (2015) 206-216.

[6] A.P.M. Velenturf, S.A. Archer, H.I. Gomes, B. Christgen, A.J. Lag-Brotons, P. Purnell, Circular economy and the matter of integrated resources, Science of The Total Environment, 689 (2019) 963-969.

[7] H.I. Gomes, V. Funari, R. Ferrari, Bioleaching for resource recovery from low-grade wastes like fly and bottom ashes from municipal incinerators: A SWOT analysis, Sci. Total Environ., 715 (2020) 136945. 
[8] M.L.M. Rodrigues, K.C.S. Lopes, H.C. Leôncio, L.A.M. Silva, V.A. Leão, Bioleaching of fluoride-bearing secondary copper sulphides: Column experiments with Acidithiobacillus ferrooxidans, Chemical Engineering Journal, 284 (2016) 1279-1286.

[9] Y. Yang, M. Diao, K. Liu, L. Qian, A.V. Nguyen, G. Qiu, Column bioleaching of lowgrade copper ore by Acidithiobacillus ferrooxidans in pure and mixed cultures with a heterotrophic acidophile Acidiphilium sp, Hydrometallurgy, 131-132 (2013) 93-98. [10] H.I. Gomes, V. Funari, W.M. Mayes, M. Rogerson, T.J. Prior, Recovery of Al, Cr and V from steel slag by bioleaching: Batch and column experiments, Journal of Environmental Management, 222 (2018) 30-36.

[11] H. Srichandan, R.K. Mohapatra, P.K. Parhi, S. Mishra, Bioleaching approach for extraction of metal values from secondary solid wastes: A critical review, Hydrometallurgy, 189 (2019) 105122.

[12] V. Funari, J. Makinen, J. Salminen, R. Braga, E. Dinelli, H. Revitzer, Metal removal from Municipal Solid Waste Incineration fly ash: A comparison between chemical leaching and bioleaching, Waste Manag, 60 (2017) 397-406.

[13] V. Funari, H.I. Gomes, M. Cappelletti, S. Fedi, E. Dinelli, M. Rogerson, W.M. Mayes, M. Rovere, Optimization routes for the bioleaching of MSWI fly and bottom ashes using microorganisms collected from a natural system, Waste Biomass Valoris., 10 (2019) 38333842.

[14] G.M. Kirkelund, C. Magro, P. Guedes, P.E. Jensen, A.B. Ribeiro, L.M. Ottosen, Electrodialytic removal of heavy metals and chloride from municipal solid waste incineration fly ash and air pollution control residue in suspension - test of a new two compartment experimental cell, Electrochimica Acta, 181 (2015) 73-81. 
[15] W. Chen, G.M. Kirkelund, P.E. Jensen, L.M. Ottosen, Electrodialytic extraction of Cr from water-washed MSWI fly ash by changing $\mathrm{pH}$ and redox conditions, Waste Management, 71 (2018) 215-223.

[16] Y.B. Acar, A.N. Alshawabkeh, Principles of electrokinetic remediation, Environmental Science \& Technology, 27 (1993) 2638-2647.

[17] V.K. Nguyen, M.-G. Ha, S. Shin, M. Seo, J. Jang, S. Jo, D. Kim, S. Lee, Y. Jung, P. Kang, C. Shin, Y. Ahn, Electrochemical effect on bioleaching of arsenic and manganese from tungsten mine wastes using Acidithiobacillus spp, Journal of Environmental Management, $223(2018)$ 852-859.

[18] A. Selvi, R. Aruliah, A statistical approach of zinc remediation using acidophilic bacterium via an integrated approach of bioleaching enhanced electrokinetic remediation (BEER) technology, Chemosphere, 207 (2018) 753-763.

[19] N. Semerci, B. Kunt, B. Calli, Phosphorus recovery from sewage sludge ash with bioleaching and electrodialysis, International Biodeterioration \& Biodegradation, 144 (2019) 104739.

[20] A.A. Moya, P. Sistat, Chronoamperometric response of ion-exchange membrane systems, Journal of Membrane Science, 444 (2013) 412-419.

[21] T. Ramanathan, Y.-P. Ting, Alkaline bioleaching of municipal solid waste incineration fly ash by autochthonous extremophiles, Chemosphere, 160 (2016) 54-61.

[22] D.E. Rawlings, Heavy metal mining using microbes, Annual Review of Microbiology, $56(2002) 65-91$.

[23] J. Niu, J. Deng, Y. Xiao, Z. He, X. Zhang, J.D. Van Nostrand, Y. Liang, Y. Deng, X. Liu, H. Yin, The shift of microbial communities and their roles in sulfur and iron cycling in a copper ore bioleaching system, Sci Rep, 6 (2016) 34744-34744. 
[24] W. Sand, T. Gehrke, P.-G. Jozsa, A. Schippers, (Bio)chemistry of bacterial leachingdirect vs. indirect bioleaching, Hydrometallurgy, 59 (2001) 159-175.

[25] T. Meisel, N. Schöner, V. Paliulionyte, E. Kahr, Determination of Rare Earth Elements, Y, Th, Zr, Hf, Nb and Ta in Geological Reference Materials G-2, G-3, SCo-1 and WGB-1 by Sodium Peroxide Sintering and Inductively Coupled Plasma-Mass Spectrometry, Geostandards Newsletter, 26 (2002) 53-61.

[26] R Development Core Team, R: A language and environment for statistical computing, R Foundation for Statistical Computing, Vienna, Austria. URL https://www.R-project.org/. 2017.

[27] H.I. Gomes, W.M. Mayes, M. Rogerson, D.I. Stewart, I.T. Burke, Alkaline residues and the environment: a review of impacts, management practices and opportunities, Journal of Cleaner Production, 112 (2016) 3571-3582.

[28] D.E. Rawlings, Characteristics and adaptability of iron- and sulfur-oxidizing microorganisms used for the recovery of metals from minerals and their concentrates, Microb Cell Fact, 4 (2005) 13-13.

[29] J. Tang, M. Su, Q. Wu, L. Wei, N. Wang, E. Xiao, H. Zhang, Y. Wei, Y. Liu, C. Ekberg, B.-M. Steenari, T. Xiao, Highly efficient recovery and clean-up of four heavy metals from MSWI fly ash by integrating leaching, selective extraction and adsorption, Journal of Cleaner Production, 234 (2019) 139-149.

[30] I. Hassan, E. Mohamedelhassan, E.K. Yanful, Z.-C. Yuan, A review article: Electrokinetic bioremediation current knowledge and new prospects, Advances in Microbiology, 6 (2016) 57.

[31] X. Wei, D. Liu, W. Huang, W. Huang, Z. Lei, Simultaneously enhanced Cu bioleaching from E-wastes and recovered $\mathrm{Cu}$ ions by direct current electric field in a bioelectrical reactor, Bioresource Technology, (2019) 122566. 
[32] T. Huang, D. Li, L. Kexiang, Y. Zhang, Heavy metal removal from MSWI fly ash by electrokinetic remediation coupled with a permeable activated charcoal reactive barrier, Scientific Reports, 5 (2015) 15412.

[33] M. Villen-Guzman, B. Arhoun, C. Vereda-Alonso, C. Gomez-Lahoz, J.M. RodriguezMaroto, J.M. Paz-Garcia, Electrodialytic processes in solid matrices. New insights into battery recycling. A review, Journal of Chemical Technology \& Biotechnology, 94 (2019) $1727-1738$.

[34] J.M. Paz-Garcia, M. Villén Guzmán, M.d.M. Cerrillo-González, Reusing and recycling of secondary batteries, Sustainable Energy Storage Days in Madrid. Spanish National Research Council. 8-11th October, Madrid, Spain, 2019.

[35] D. Appy, H. Lei, C.-Z. Wang, M.C. Tringides, D.-J. Liu, J.W. Evans, P.A. Thiel, Transition metals on the $\left(\begin{array}{llll}0 & 0 & 0 & 1\end{array}\right)$ surface of graphite: Fundamental aspects of adsorption, diffusion, and morphology, Progress in surface science, 89 (2014) 219-238.

[36] L.M. Ottosen, A.T. Lima, A.J. Pedersen, A.B. Ribeiro, Electrodialytic extraction of Cu, $\mathrm{Pb}$ and $\mathrm{Cl}$ from municipal solid waste incineration fly ash suspended in water, Journal of Chemical Technology \& Biotechnology, 81 (2006) 553-559. 
Figure 1 - Diagram of the experimental setup used based on the two-compartment setup developed and patented at DTU (PCT/EP2014/068956) [13]. In the bioleaching experiment, no direct current was applied. The cell stood in an orbital shaker for the duration of the experiments $(150 \mathrm{rpm})$.

Figure $2-\mathrm{pH}$ variation in the a) anolyte and b) catholyte during the experiments.

Figure 3 - Metal concentration measured in the anolyte during the experiments - a) Cr; b) $\mathrm{Cu}$; c) $\mathrm{Zn}$, d) $\mathrm{Li}$, e) $\mathrm{Co}, \mathrm{f}) \mathrm{Pb}, \mathrm{g}$ ) $\mathrm{Ni}$ and h) $\mathrm{Cd}$ (logarithmic scale).

Figure 4 - Metal concentration measured in the catholyte during the experiments - a) Cr; b) $\mathrm{Cu}$; c) $\mathrm{Zn}$, d) Li, e) Co, f) Pb, g) Ni and h) Cd (logarithmic scale).

Figure 5-Chronoamperometry of the experiment combining electrodialytic treatment (ED) with bioleaching. Potential step (a) obtained by setting a cell voltage of $1 \mathrm{~V}$ between anolyte and catholyte and simultaneously reading the value of the electrode potentials (b). Zooming of the first $2000 \mathrm{~s}$ window (c) reveals how the circuit is forced in the opposite direction to the current flow that is spontaneously generated by the cell. Figure 6 - Metal percentages in the catholyte, anolyte, cathode, anode, and cation exchange membrane in each experiment. 




Fig. 1 

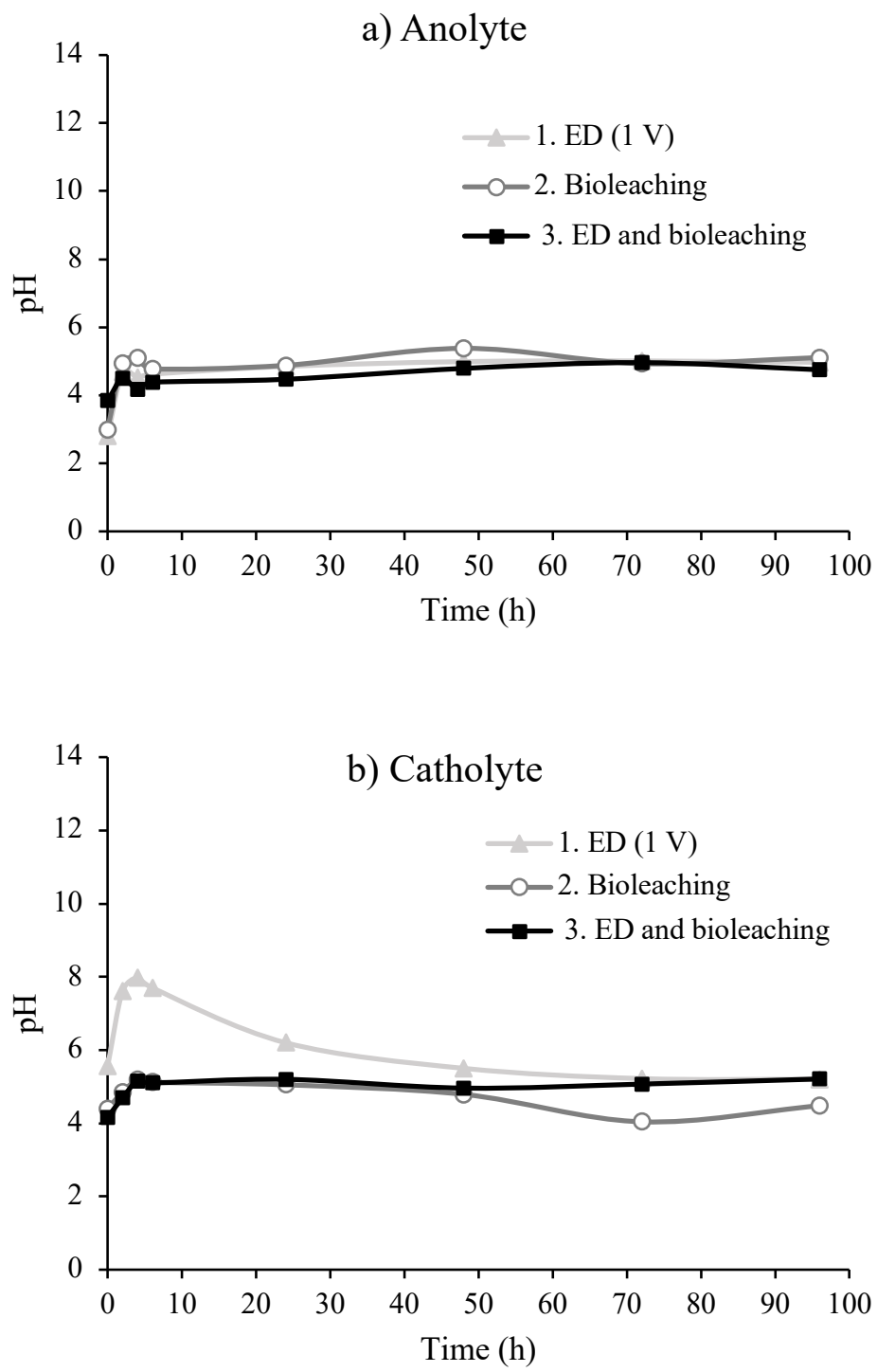

Fig. 2 

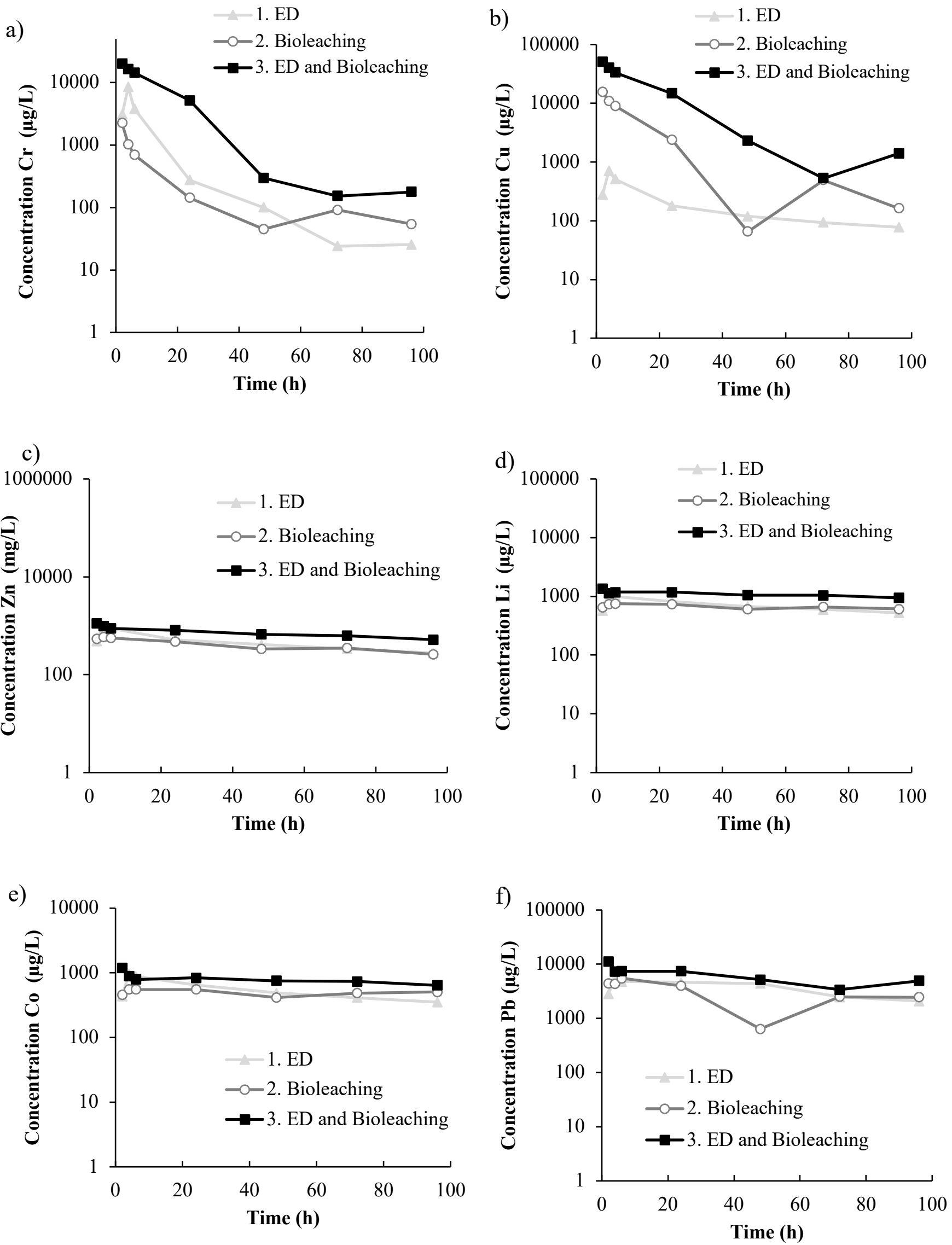

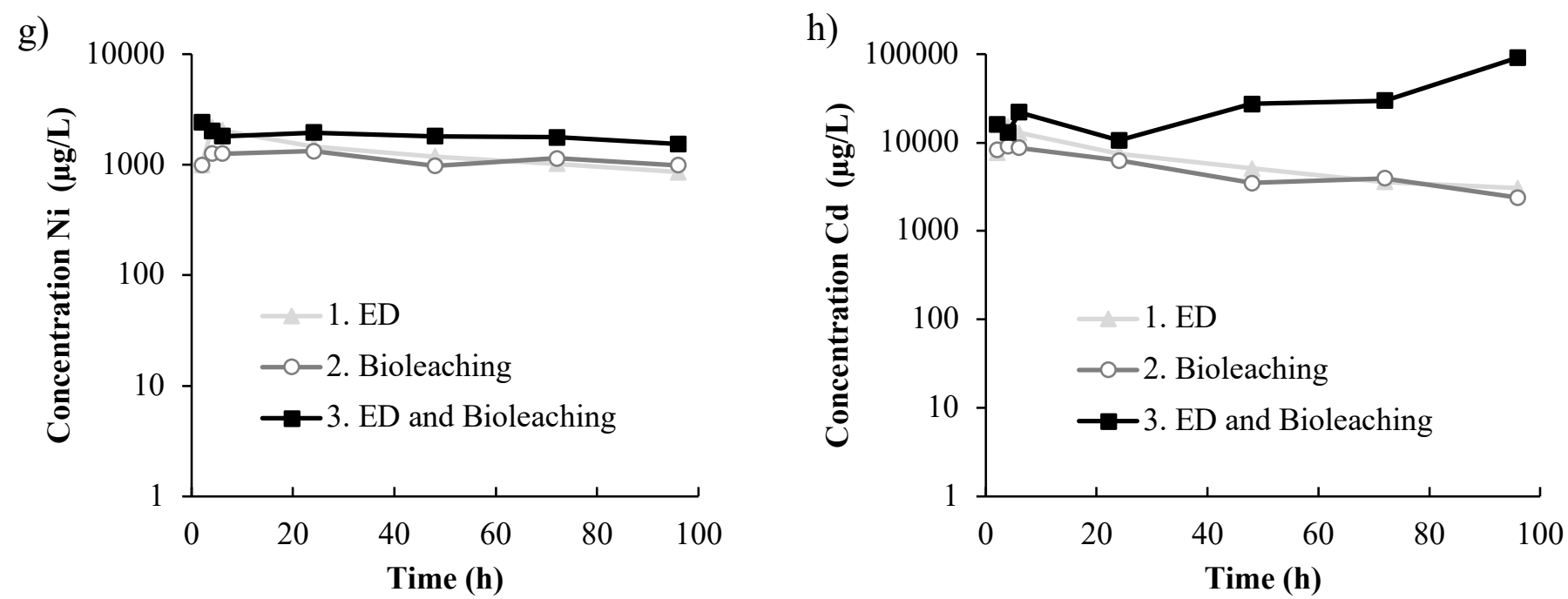

Fig. 3 
a)

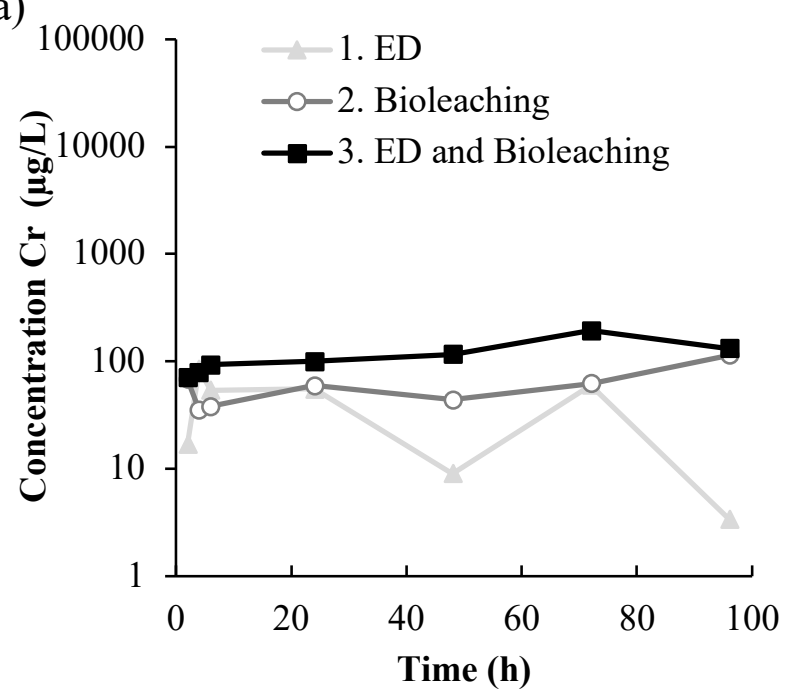

c)

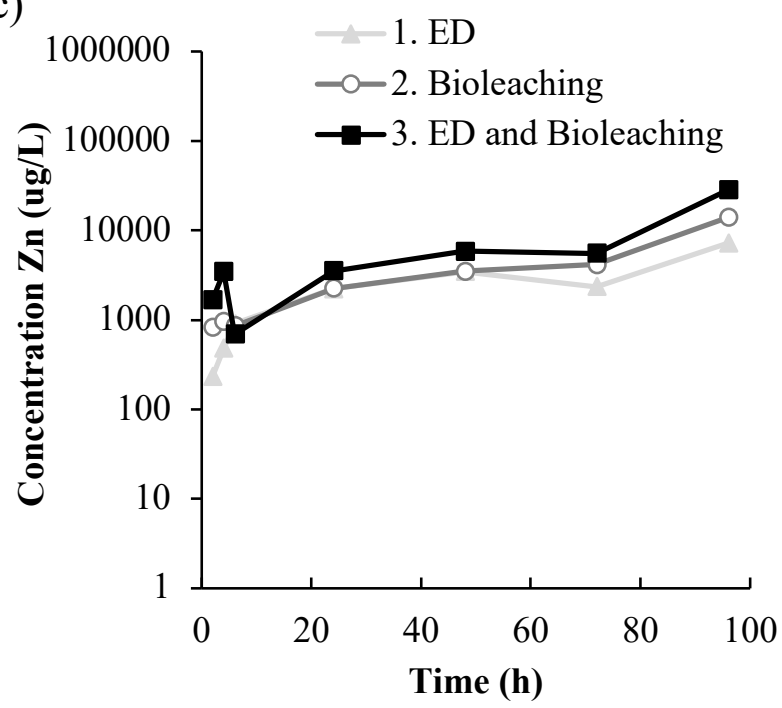

e)

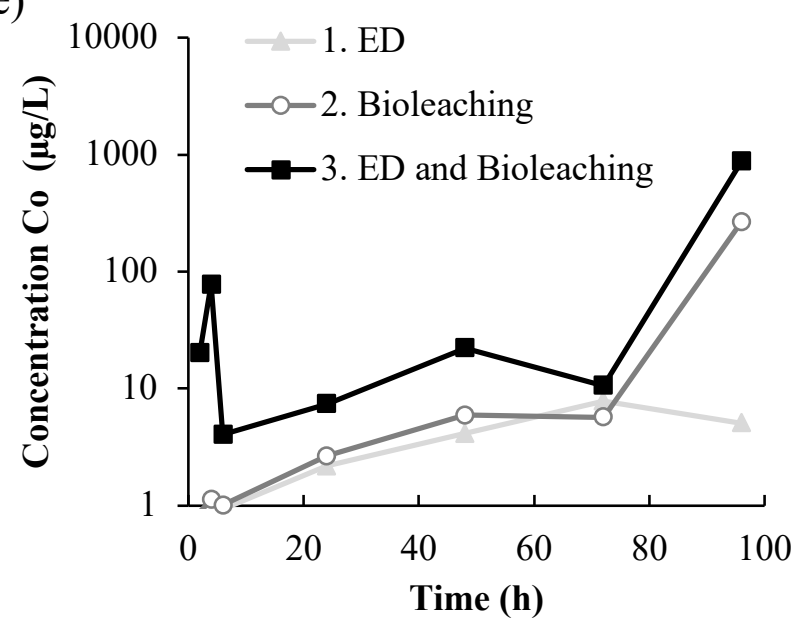

b)

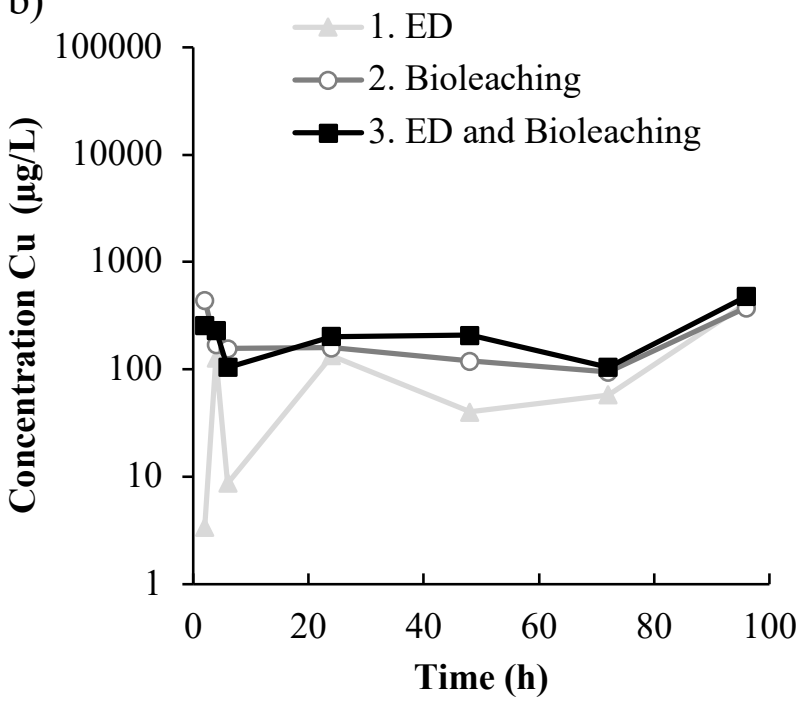

d)

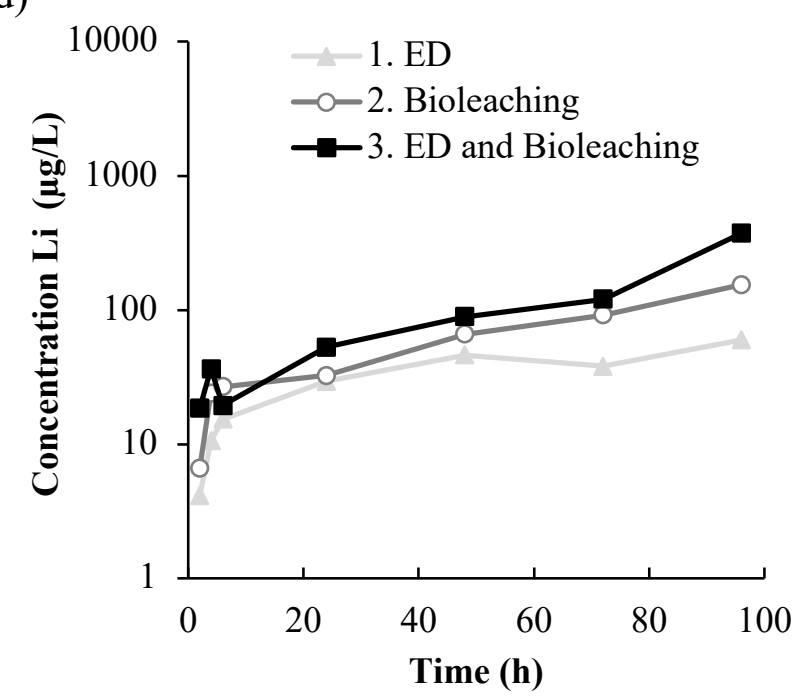

f)

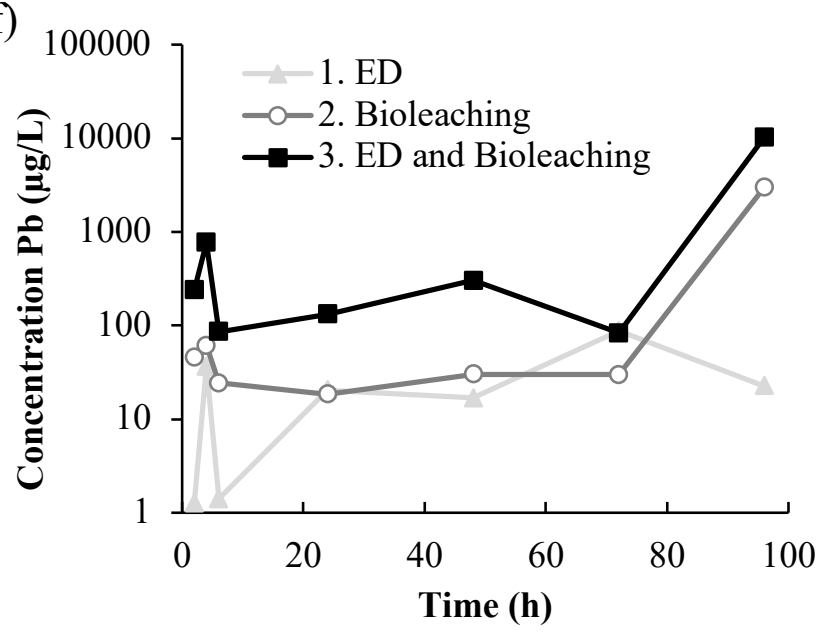


g)



h)

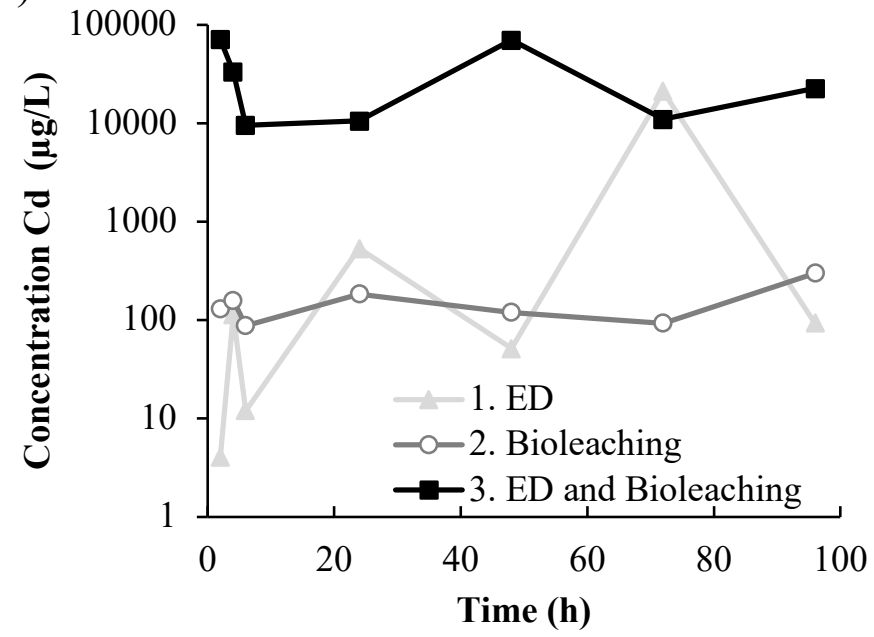

Fig. 4 

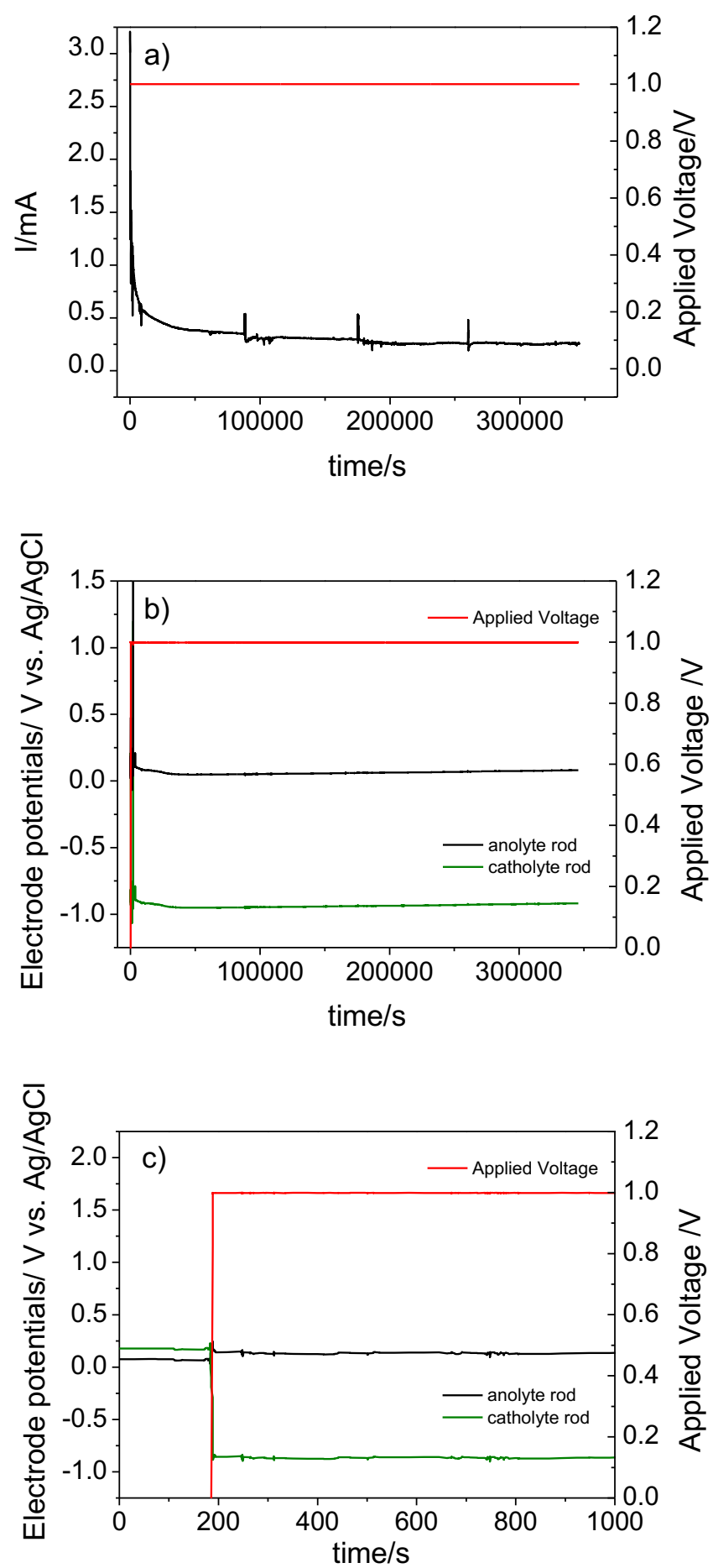

Fig. 5 
$\mathrm{Cr}$

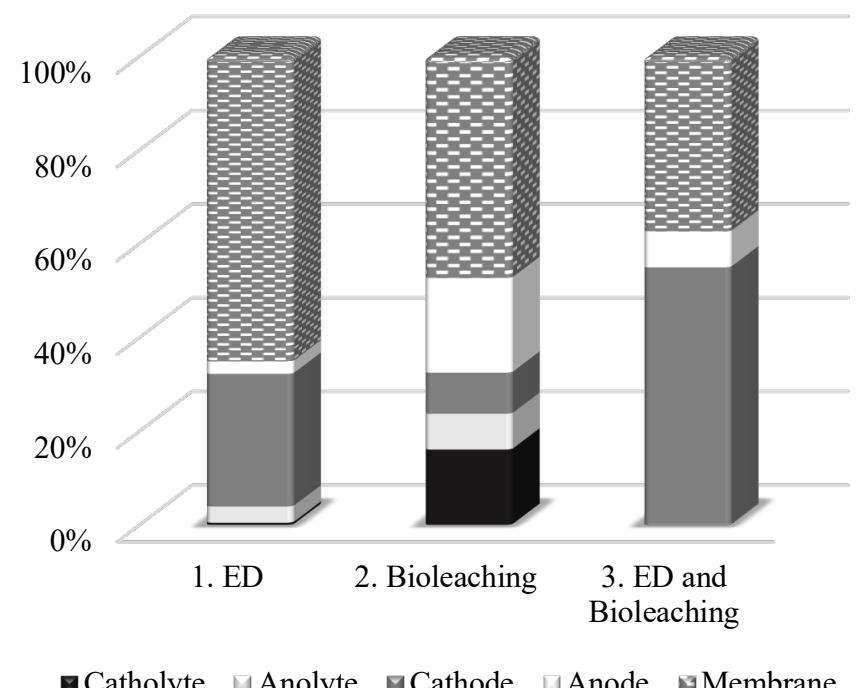

-Catholyte $\Delta$ Anolyte $\square$ Cathode $\sqcup$ Anode Membrane

\section{Cd}

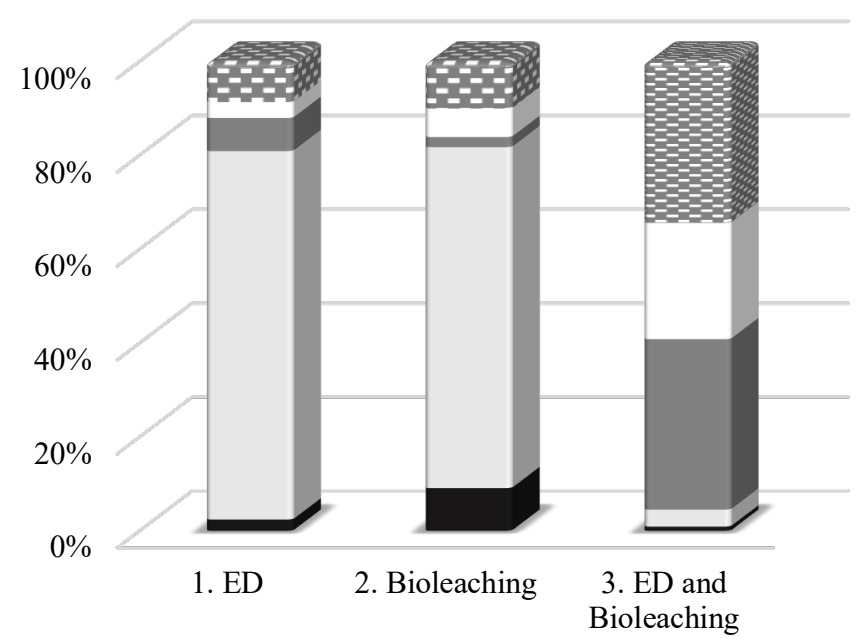

घCatholyte $\backsim$ Anolyte $\square$ Cathode $\sqcup$ Anode $\square$ Membrane
$\mathrm{Cu}$

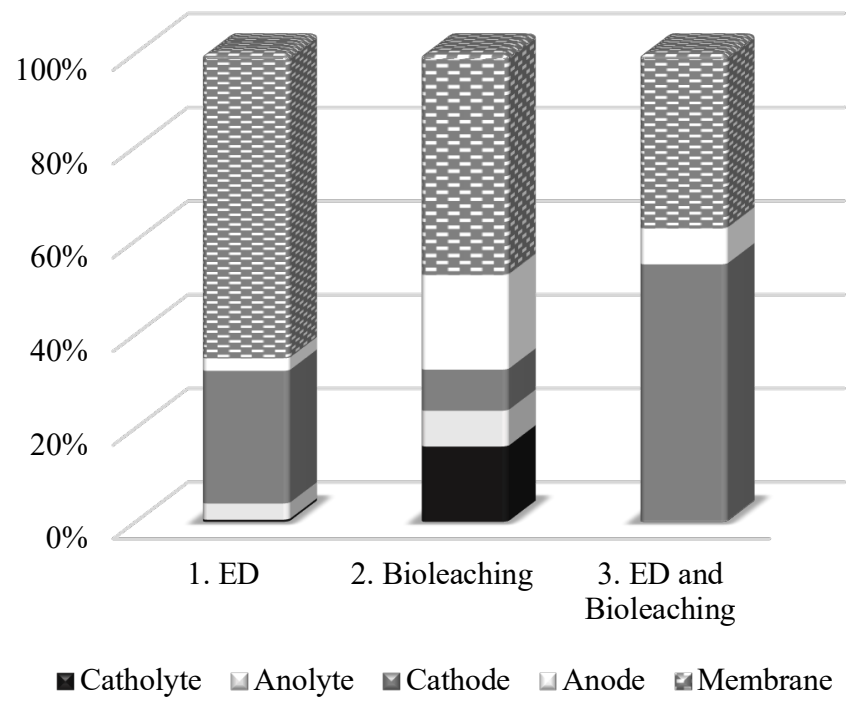

Li

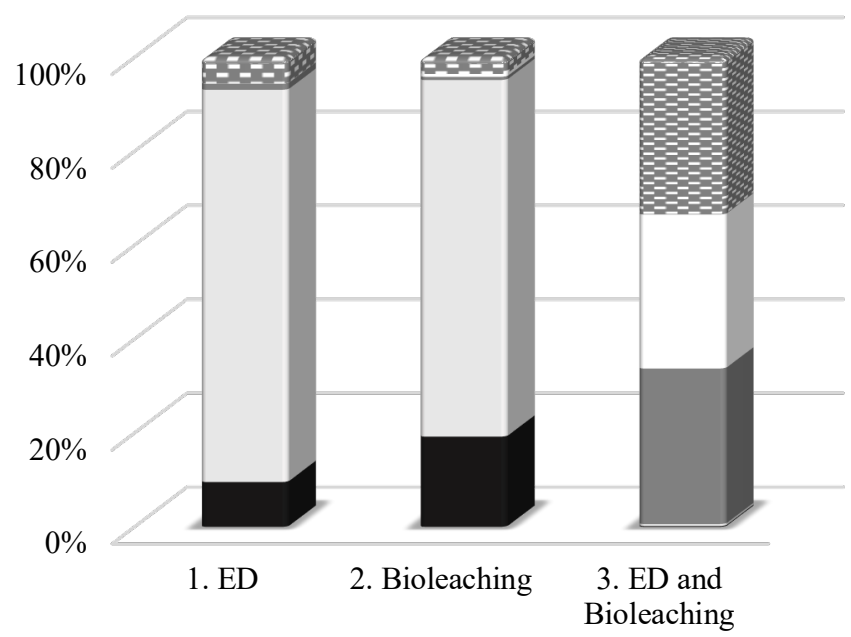

घCatholyte $\sqcup$ Anolyte $\square$ Cathode $\sqcup$ Anode $\square$ Membrane

Fig. 6 
Table 1. Chemical composition of the starting material determined by inductively coupled plasma mass spectrometry after total digestion of SFA solid sample.

Table 2. Experimental conditions tested.

Table 3. Metal concentration in the anolyte $\left(\mu \mathrm{g} \mathrm{L}^{-1}\right)$ at $\mathrm{t}=2 \mathrm{~h}$ and $=96 \mathrm{~h}$ and percentage variation between the two calculated as $\frac{C_{2}-C_{96}}{C_{2}} \times 100$, where $\mathrm{C}_{2}$ and $\mathrm{C}_{96}$ are the concentrations at those times.

Table 4. Results of the two-way repeated measures ANOVA considering the totality of data and detailing for experimental conditions (electrodialytic process, bioleaching, bioleaching and electrodialysis) and cell compartments (anolyte, anode, membrane, cathode, catholyte). Values marked in bold are statistically significant.

Table 5. Measured concentration ( $\mathrm{mg} \mathrm{kg}^{-1}$ or $\left.\mathrm{ppm}\right)$ in catholyte, anolyte, corresponding electrodes, and membrane of the ED+Bioleaching experiment under controlled chronoamperometry mode. Total moles for each element according the mass balance of the experiment and relative atomic masses are also reported. 
Table 1

\begin{tabular}{|c|c|c|}
\hline Element & Unit & Concentration \\
\hline $\mathrm{Ca}$ & $\mathrm{g} / 100 \mathrm{~g}$ & 38 \\
\hline $\mathrm{Si}$ & $"$ & 30 \\
\hline $\mathrm{Al}$ & $"$ & 11 \\
\hline K & $"$ & 6.2 \\
\hline $\mathrm{P}$ & $"$ & 3.5 \\
\hline $\mathrm{Mg}$ & $"$ & 3.2 \\
\hline $\mathrm{Ti}$ & $"$ & 2.5 \\
\hline $\mathrm{Fe}$ & $"$ & 2.4 \\
\hline $\mathrm{Zn}$ & $"$ & 1.2 \\
\hline $\mathrm{Pb}$ & $\mathrm{mg} / \mathrm{kg}$ & 3586 \\
\hline $\mathrm{Cr}$ & $"$ & 941 \\
\hline $\mathrm{Cu}$ & $"$ & 910 \\
\hline $\mathrm{Ba}$ & $"$ & 852 \\
\hline $\mathrm{Sn}$ & $"$ & 665 \\
\hline $\mathrm{Mn}$ & $"$ & 605 \\
\hline $\mathrm{Sr}$ & " & 463 \\
\hline $\mathrm{Cd}$ & $"$ & 107 \\
\hline $\mathrm{Rb}$ & $"$ & 106 \\
\hline $\mathrm{Ni}$ & $"$ & 76 \\
\hline $\mathrm{Zr}$ & $"$ & 66 \\
\hline $\mathrm{Li}$ & $"$ & 23 \\
\hline As & $"$ & 21 \\
\hline $\mathrm{Ce}$ & $"$ & 21 \\
\hline Co & $"$ & 21 \\
\hline V & $"$ & 20 \\
\hline Mo & $"$ & 18 \\
\hline $\mathrm{La}$ & $"$ & 12 \\
\hline $\mathrm{Se}$ & $"$ & 11 \\
\hline $\mathrm{Nb}$ & $"$ & 11 \\
\hline Y & $"$ & 9.9 \\
\hline Cs & $"$ & 4.8 \\
\hline Sc & $"$ & 4.4 \\
\hline Th & $"$ & 2.8 \\
\hline $\mathrm{U}$ & $"$ & 1.0 \\
\hline
\end{tabular}


Table 2

\begin{tabular}{clll}
\hline Experiment & Technology & Catholyte & Anolyte \\
\hline 1 & Electrodialysis & $0.01 \mathrm{~m} \mathrm{NaCl}$ & $\begin{array}{l}5 \mathrm{~g} \text { fly ash, } 50 \mathrm{~mL} \text { modified } 9 \mathrm{~K} \\
\text { medium, } 0.5 \mathrm{~mL} \text { concentrated } \mathrm{H}_{2} \mathrm{SO}_{4}\end{array}$ \\
2 & Bioleaching & $0.01 \mathrm{~m} \mathrm{NaCl}$ & $\begin{array}{l}5 \mathrm{~g} \text { fly ash, } 5 \mathrm{~mL} \text { bacteria inoculum } \\
\text { and } 45 \mathrm{~mL} \text { modified } 9 \mathrm{~K} \text { medium, } 0.5 \\
\mathrm{~mL} \text { concentrated } \mathrm{H}_{2} \mathrm{SO}_{4}\end{array}$ \\
3 & $\begin{array}{l}\text { Electrodialysis and } \\
\text { bioleaching }\end{array}$ & $0.01 \mathrm{~m} \mathrm{NaCl}$ & $\begin{array}{l}5 \mathrm{~g} \text { fly ash, } 5 \mathrm{~mL} \text { bacteria inoculum } \\
\text { and } 45 \mathrm{~mL} \text { modified } 9 \mathrm{~K} \text { medium, } 0.5 \\
\text { mL concentrated } \mathrm{H}_{2} \mathrm{SO}_{4}\end{array}$ \\
\hline
\end{tabular}




\section{Table 3}

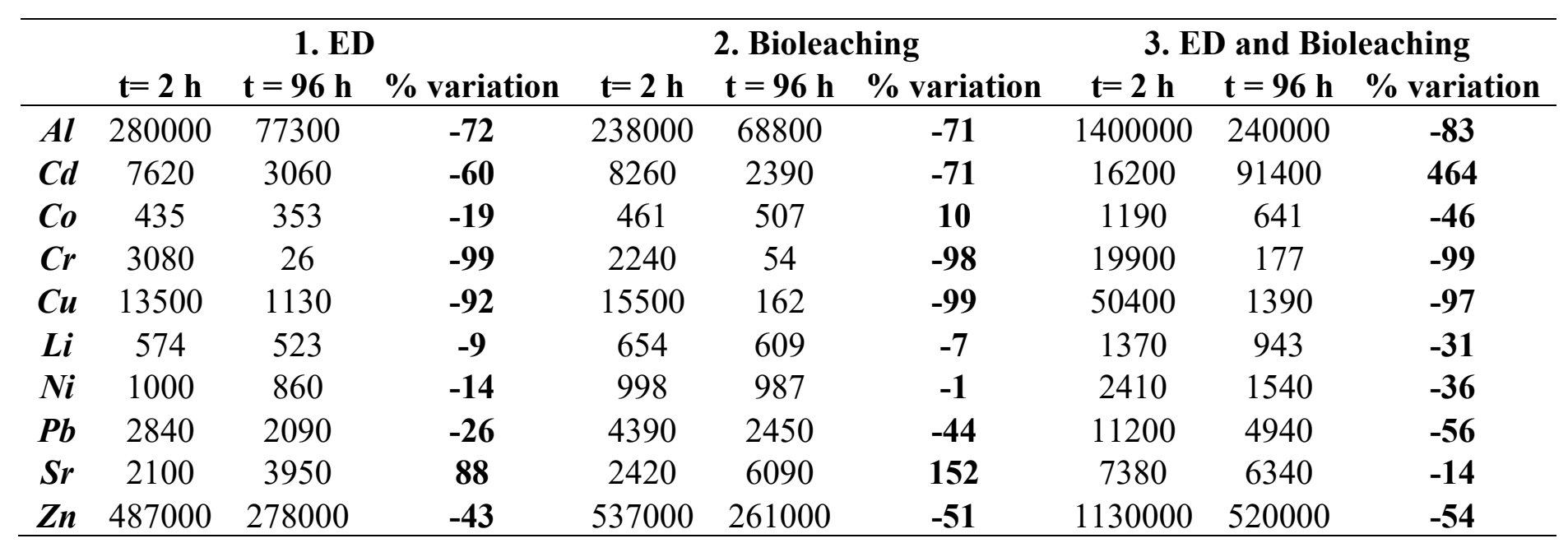


Table 4

\begin{tabular}{clll}
\hline & Experimental setup & Cell compartment & Interaction effect \\
\hline \multirow{2}{*}{$\boldsymbol{l} \boldsymbol{l}$} & $\mathrm{F}(1,3)=20.856$, & $\mathrm{F}(1,2)=9.656$, & $\mathrm{F}(1,5)=19.598$, \\
& $\eta^{2}=0.26, \mathbf{p}<\mathbf{0 . 0 0 1}$ & $\eta^{2}=0.09, \mathbf{p}<\mathbf{0 . 0 0 1}$ & $\eta^{2}=0.44, \mathbf{p}<\mathbf{0 . 0 0 1}$ \\
$\boldsymbol{C} \boldsymbol{d}$ & $\mathrm{F}(1,3)=5.782$, & $\mathrm{F}(1,2)=4.438$, & $\mathrm{F}(1,5)=3.697$, \\
& $\eta^{2}=0.17, \mathbf{p}=\mathbf{0 . 0 0 2}$ & $\eta^{2}=0.09, \mathbf{p}=\mathbf{0 . 0 1}$ & $\eta^{2}=0.26, \mathbf{p}=\mathbf{0 . 0 0 6}$ \\
$\boldsymbol{C} \boldsymbol{o}$ & $\mathrm{F}(1,3)=3.984$, & $\mathrm{F}(1,2)=3.491$, & $\mathrm{F}(1,5)=2.848$, \\
& $\eta^{2}=0.18, \mathbf{p}=\mathbf{0 . 0 1}$ & $\eta^{2}=0.08, \mathbf{p}=\mathbf{0 . 0 4}$ & $\eta^{2}=0.17, \mathbf{p}=\mathbf{0 . 0 2}$ \\
$\boldsymbol{C} \boldsymbol{r}$ & $\mathrm{F}(1,3)=4.857$, & $\mathrm{F}(1,2)=3.805$, & $\mathrm{F}(1,5)=4.238$, \\
& $\eta^{2}=0.17, \mathbf{p}=\mathbf{0 . 0 0 5}$ & $\eta^{2}=0.07, \mathbf{p}=\mathbf{0 . 0 3}$ & $\eta^{2}=0.22, \mathbf{p}=\mathbf{0 . 0 0 3}$ \\
$\boldsymbol{C} \boldsymbol{u}$ & $\mathrm{F}(1,3)=3.545$, & $\mathrm{F}(1,2)=4.925$, & $\mathrm{F}(1,5)=4.261$, \\
& $\eta^{2}=0.11, \mathbf{p}=\mathbf{0 . 0 2}$ & $\eta^{2}=0.10, \mathbf{p}=\mathbf{0 . 0 1}$ & $\eta^{2}=0.23, \mathbf{p}=\mathbf{0 . 0 0 2}$ \\
$\boldsymbol{L} \boldsymbol{i}$ & $\mathrm{F}(1,3)=4.045$, & $\mathrm{F}(1,2)=3.648$, & $\mathrm{F}(1,5)=2.983$, \\
& $\eta^{2}=0.13, \mathbf{p}=\mathbf{0 . 0 1}$ & $\eta^{2}=0.08, \mathbf{p}=\mathbf{0 . 0 3}$ & $\eta^{2}=0.17, \mathbf{p}=\mathbf{0 . 0 2}$ \\
$\boldsymbol{N} \boldsymbol{i}$ & $\mathrm{F}(1,3)=3.893$, & $\mathrm{F}(1,2)=3.331$, & $\mathrm{F}(1,5)=2.699$, \\
& $\eta^{2}=0.13, \mathbf{p}=\mathbf{0 . 0 1}$ & $\eta^{2}=0.08, \mathbf{p}=\mathbf{0 . 0 4}$ & $\eta^{2}=0.16, \mathbf{p}=\mathbf{0 . 0 3}$ \\
$\boldsymbol{P b}$ & $\mathrm{F}(1,3)=4.890$, & $\mathrm{F}(1,2)=6.869$, & $\mathrm{F}(1,5)=5.426$, \\
& $\eta^{2}=0.13, \mathbf{p}=\mathbf{0 . 0 0 5}$ & $\eta^{2}=0.13, \mathbf{p}=\mathbf{0 . 0 0 2}$ & $\eta^{2}=0.25, \mathbf{p}<\mathbf{0 . 0 0 1}$ \\
$\boldsymbol{S} \boldsymbol{r}$ & $\mathrm{F}(1,3)=3.735$, & $\mathrm{F}(1,2)=2.798$, & $\mathrm{F}(1,5)=2.258$, \\
& $\eta^{2}=0.14, \mathbf{p}=\mathbf{0 . 0 2}$ & $\eta^{2}=0.07, \mathbf{p}=0.07$ & $\eta^{2}=0.14, \mathrm{p}=0.06$ \\
$\boldsymbol{Z} \boldsymbol{n} \boldsymbol{F}$ & $\mathrm{F}(1,3)=4.088$, & $\mathrm{F}(1,2)=3.933$, & $\mathrm{F}(1,5)=3.230$, \\
& $\eta^{2}=0.13, \mathbf{p}=\mathbf{0 . 0 1}$ & $\eta^{2}=0.09, \mathbf{p}=\mathbf{0 . 0 3}$ & $\eta^{2}=0.18, \mathbf{p}=\mathbf{0 . 0 1}$ \\
\hline
\end{tabular}


Table 5

\begin{tabular}{ccccccc}
\hline Element & $\begin{array}{c}\text { Conc in } \\
\text { catholyte }\end{array}$ & $\begin{array}{c}\text { Conc in } \\
\text { anolyte }\end{array}$ & $\begin{array}{c}\text { Conc in C- } \\
\text { electrode }\end{array}$ & $\begin{array}{c}\text { Conc in A- } \\
\text { electrode }\end{array}$ & $\begin{array}{c}\text { Conc in } \\
\text { membrane }\end{array}$ & $\begin{array}{c}\text { Total moles } \\
\text { in 50 mL } \\
\text { solution }\end{array}$ \\
\hline $\mathrm{Al}$ & 30000 & 14 & 0.2 & 6 & 1.2 & $5.56 \mathrm{E}-02$ \\
$\mathrm{Ca}$ & 340 & 14 & 2.6 & 9 & 8.9 & $4.67 \mathrm{E}-04$ \\
$\mathrm{Zn}$ & 358 & 22 & 0.3 & 2 & 0.8 & $2.93 \mathrm{E}-04$ \\
$\mathrm{Ti}$ & 145 & 0.6 & 0.01 & 0.4 & 0.1 & $1.53 \mathrm{E}-04$ \\
$\mathrm{Mn}$ & 43 & 1.7 & 0.02 & 0.1 & 0.06 & $4.06 \mathrm{E}-05$ \\
$\mathrm{Cu}$ & 28 & 4.4 & 2.2 & 0.8 & 0.06 & $2.82 \mathrm{E}-05$ \\
$\mathrm{Cr}$ & 28 & 0.2 & 0.01 & 0.08 & 0.03 & $2.75 \mathrm{E}-05$ \\
$\mathrm{Sr}$ & 9 & 0.3 & 0.05 & 0.08 & 0.05 & $5.17 \mathrm{E}-06$ \\
$\mathrm{~Pb}$ & 13 & 1 & 0.04 & 0.5 & 0.6 & $3.56 \mathrm{E}-06$ \\
\hline
\end{tabular}

